\title{
Ecological and socio-economic assessment of Kenyan coastal fisheries: the case of Malindi-Ungwana Bay artisanal fisheries versus semi-industrial bottom trawling'
}

\author{
Cosmas Nzaka Munga (1,2), Edward Kimani (1) \& \\ Ann Vanreusel (2) \\ (I) Kenya Marine and Fisheries Research Institute, Kenya \\ (2) Marine Biology Research Group, Gent University, Belgium
}

\begin{abstract}
This study explores and describes the status of the fisheries resources in the Malindi-Ungwana Bay, Kenya. In addition to shrimp bottom trawling, the bay also supports a variety of artisanal fishing techniques with associated resource-use conflict experienced for quite some time until a ban on bottom trawling was imposed. This study therefore, focuses on a before and after the trawling ban effect on shrimp populations and finfish bycatch distribution and abundance, and the characterisation of artisanal finfish catches in terms of catch composition, catch-per-unit-effort, and mean trophic level by vessel-gear categories. Apart from providing the current status of exploitation level of the fisheries resources, the scientific information generated from this study is also useful for the revision of the shrimp fishery management plan that was formulated with inadequate scientific and background information during the six year bottom trawling ban in the bay.
\end{abstract}

Key words: Shrimp bottom trawling, artisanal catches, resource-use conflict, Malindi-Ungwana Bay, Kenya

The ecological consequences of, and socio-economic interactions between the small scale artisanal fishery and the semi-industrial bottom trawl fishery, as well as artisanal fishers' alternative livelihoods and perceptions of bottom trawling have been analysed for the Malindi-Ungwana Bay, Kenya. The bay is located between the latitudes $2^{\circ} 30^{\prime} \mathrm{S}$ and $3^{\circ} 30^{\prime} \mathrm{S}$, and the longitudes $40^{\circ} 00^{\prime} \mathrm{E}$ and $41^{\circ} \mathrm{O} 0^{\prime} \mathrm{E}$ covering a coastal area of about 200 $\mathrm{km}$ long. Bottom trawling targets shrimps but at the same time produces bycatch. Both artisanal fishing and bottom trawling have been practiced for several decades in the bay since the r 960 . With time, conflicts emerged ostensibly due to excessive trawl bycatches otherwise targeted by the artisanal fishers, the perceived environmental degradation, and 
the damage of artisanal fishing gear by the trawlers. The oversupply of retained trawl bycatches to the local fish markets resulted in cheap fish prices that competed unfairly with fish sold by the artisanal fishers. This conflict persisted for some time until a ban on bottom trawling was imposed in September 2006. This thenpaved the way for the formulation of the shrimp fishery management plan, six years after the trawling ban. This study therefore, determined the status of the fisheries of the Malindi-Ungwana Bay, before and after the trawling ban and analysed artisanal fishers' alternative livelihoods and their perceptions of shrimp bottom trawling after the ban was lifted in July 201 .

First, a retrospective analysis of some historical data on artisanal and trawl annual catches before and after the ban was conducted. Further, shore-based artisanal catch assessments after the trawl ban between 2009-201 covering the dry Northeast Monsoon (NEM) and the wet Southeast Monsoon (SEM) seasons were conducted after every three months annually, and catch composition, catch-per-unit-effort (CPUE) and mean trophic level were analysed by vessel-gear combination. In addition, two experimental bottom trawl surveys covering both the NEM and SEM seasons identified the composition, distribution patterns and abundance of penaeid shrimps and associated finfish bycatches in the bay. The socio-economic assessment identified alternative livelihoods for the different categories of artisanal fishers operating in the bay, and the Net Present Value (NPV) calculated the economic viability for each artisanal fishing category. Finally, using semi-structured interviews, the artisanal fishers' perceptions of shrimp trawling in the bay were also identified.

The results of the before and after bottom trawling ban for both trawl and artisanal catches were based on aggregated catch data. Artisanal catches of mostly finfish species showed a decline before the ban, but rapidly recovered within 2 years after the ban. The artisanal shrimp catches were low at less than roo tannually and this remained unchanged six years before and two years after the trawling ban. On the other hand, commercial shrimp catches showed a gradual decline before the ban from $550 t$ in 2001 to $250 t$ in 2006, and the shrimp to bycatch ratio was I:I.5 compared to values in early reports of $I: 7$ in 1999 . A distinct artisanal catch composition was evident between the fishing areas of Tana and Sabaki of the extensive Malindi-Ungwana Bay. This distinct composition was attributed to more abundant freshwater fish families of Claridae, Cichlidae and Protopteridae in Tana, and more abundant marine fish families of Carangidae, Siganidae, Carcharhinidae and Lethrinidae including mixed pelagic and mixed demersal fish groups in Malindi. Current catch data using shore-based assessments and experimental trawl surveys before the ban was lifted provided a detailed status of the Malindi-Ungwana Bay fisheries resources.

The shore-based artisanal catch assessment described the finfish catch composition (total number of species caught, sizes and mean trophic levels), and catch-per-uniteffort (CPUE) for each of the most popular vessel-gear categories used in the bay. Specific vessel-gear category combinations instead of the traditional gear-based approach, offers better alternative insights for monitoring catches therefore, supporting fisheries management. A total of 4,269 finfish individuals belonging to 178 species and 66 families were sampled by the 5 most popular vessel-gear categories used in the bay. Significant 
differences in species composition existed between the different vessel-gear categories with the highest number of species caught by the canoe-gillnet and the lowest number caught by the foot-handline category. The CPUE was not significantly different between vessel-gear, although this was on the average highest for canoe-gillnet and mashua-gillnet, and lowest for foot-handline. The highest mean trophic level of 4.0 was recorded for the mashua-gillnet and the lowest of 3.4 and 3.2 recorded for the canoe-gillnet and foot-seine net respectively. The mashua-gillnet, canoe-gillnet and foot-seine net were singled out as the most suitable units for monitoring the artisanal fisheries in the bay for catching individuals of the highest mean trophic level and largest sized in mashua-gillnet, the highest number of species caught in canoe-gillnet, and the smallest sized individuals in foot-seine net.

Results of the shallow water experimental trawl surveys showed distinct penaeid species composition and abundance patterns between the near shore areas of the Tana and Sabaki estuaries, attributed mainly to depth, turbidity and season. Penaeus semisulcatus was more abundant at the Sabaki area, where it was deeper with a muddy bottom and less turbid waters. Fenneropenaeus indicus was more abundant in the Tana area, a shallower, more turbid area with sandy-mud sediments. Penaeus monodon, Penaeus japonicus and Metapenaeus monoceros were found in both areas, suggesting wider tolerance to environmental conditions. The shrimp total biomass and catch rates were significantly higher during the wet SEM season, and decreased with increasing depth. Small-sized M. monoceros and P. monodon individuals were abundant during the SEM season, whereas large ones with ripe and spent gonads were more common during the dry NEM season. Seasonal patterns in gonad maturity were less clear for F. indicus and P. semisulcatus. The length at first maturity $\left(\mathrm{L}_{50}\right)$ varied among the penaeid shrimp species. The $\mathrm{L}_{50}$ was largest for Penaeus monodon (4I.9 $\mathrm{mm}$ ) followed by Fenneropenaeus indicus $(37.4 \mathrm{~mm})$, Metapenaeus monoceros $(36.0 \mathrm{~mm})$ and Penaeus semisulcatus $(33.4 \mathrm{~mm})$. These differences in length at first maturity suggested the different species in the bay started spawning at different sizes, an important biological reference for sustainable resource exploitation.

The finfish bycatches associated with the experimental trawl surveys differed in catch rates, biomass and composition by area and season. Catch rates and biomass were significantly higher in the inshore than in the offshore area of the bay, and were distinct in composition, while less pronounced differences existed between the seasons. The Shannon-Wiener diversity index was significantly higher during the wet SEM season, but no differences were found between the inshore and offshore areas, nor was there a significant interaction effect. A total of 158 fish species in 6r families were identified during the dry NEM season, and 16 r species in 57 families during the wet SEM. However, only 7 families contributed for $66.6 \%$ by mass during the NEM whereas ro families contributed for $59.7 \%$ during the SEM. Comparison of the artisanal catches and trawl bycatches indicated that the inshore trawl bycatches showed a larger overlap with the composition of artisanal catches than offshore trawl bycatches. This larger overlap between the inshore trawl bycatches and artisanal catches was mainly attributed to 7 common and most abundant artisanal fish species confirming a localised inshore resource-use overlap between 
the artisanal and bottom shrimp trawling, whereas these 7 species were mostly absent in the offshore trawl bycatches. Further, significantly smaller sized individuals of these 7 species occurred in the trawl bycatches posing a potential risk for low recruitment of these fish species with continued bottom trawling. Also species diversity in both inshore and offshore trawl bycatches was significantly higher than in artisanal catches further confirming the possible resource-use overlap between the two fishery types in the Malindi-Ungwana Bay.

The socio-economic assessment using questionnaires in semi-structured interviews of ${ }_{15} \mathrm{I}$ individuals indicated that livelihood diversification in Malindi-Ungwana Bay was common among the artisanal fishers. At least five categories of artisanal fishers were identified: full time fishers, fishers with additional fish trading and other micro-businesses, fishers who used acquired skills for generating extra income, fishers who practiced additional subsistence farming, and fishers with additional part time paid-up jobs. Livelihood diversification among artisanal fishers should be encouraged although with proper choices depending on the economic viability. In this study, the full time fishers were associated with relatively higher mean daily catches and incomes compared to the rest of the fishers with additional livelihood sources. However, the Net Present Value of the different artisanal fishing categories was highest for those artisanal fishers with additional livelihood sources of fish trading and other micro-businesses, part time paid-up jobs, and those who used their acquired skills for making extra income. The Net Present Value was low for those fishers who also undertook subsistence farming, and for the full time fishers suggesting that these were not economically viable options for the artisanal fishers. The majority of artisanal fishers from all fishing categories except those who engaged in part time paid-up jobs perceived a negative impact of shrimp trawling mostly due to its associated damage to artisanal fishing gear, fish habitat, and excessive bycatch of species that are also targeted by the artisanal fishers.

Several conclusions are derived from this study. Before the bottom shrimp trawling ban in September 2006, the activity showed some negative impact due to highly fluctuating and reduced overall artisanal catches and the trawl shrimp catches. This impact was however, not pronounced for the artisanal shrimp catches signifying low or acceptable exploitation level. The artisanal fishery is multigear, multispecies and multifleet in nature as observed for the Malindi-Ungwana Bay. The mashua-gillnet, canoe-gillnet and foot-seine net were therefore identified as suitable fishing units for monitoring the artisanal catches in the bay. The relatively higher mean trophic level range of between 3.2-4.0 signified that fisheries resources in the Malindi-Ungwana Bay were still sustainably exploited. The shrimp catch rates and biomass in the bay, decreased with increase in depth and away from the shore, and were significantly higher during the wet SEM season. The Tana and Sabaki estuaries significantly differed in shrimp composition, with the shallower and more turbid Tana estuary characterised by more abundant Fenneropenaeus indicus and the deeper and and less turbid Sabaki estuary characterised by more abundant Penaeus semisulcatus. The fish species: Galeichthys feliceps, Pellona ditchela, Johnius amblycephalus, Leiognathus equulus, Pomadasys maculatus, Otolithes ruber and Lobotes surinamensis were 
more abundant both in artisanal catches and trawl bycatches and therefore, the potential species for resource overlap and conflict between bottom trawling and the artisanal fishery in the inshore area of the bay. The Net Present Value of artisanal fishing increased with some additional livelihood sources but not with subsistence farming or when full time fishing was undertaken alone. The majority of artisanal fishers from all fishing categories except those who engaged in part time paid-up jobs perceived a negative impact of shrimp trawling.

This study concludes with the following recommendations:

- Revision of the shrimp fishery management plan for the Malindi-Ungwana Bay taking into consideration findings of this study for an Ecosystem Approach to Fisheries (EAF). This is because the present shrimp fishery management plan was formulated with relatively little scientific information available by then.

- Regular monitoring for long term data of fish and shrimps on the identified biological and fishery aspects of mean sizes, mean trophic levels, catch composition, catch-per-unit-effort and size at first maturity $\left(L_{50}\right)$ using the proposed mashuagillnet, canoe-gillnet, foot-seine net and bottom trawl.

- The nature of artisanal fishing operation in nearshore is not sustainable due to increased pressure on the resources, weather and seasonal changes. The Kenya Government through the State Department of Fisheries, should initiate a program to equip artisanal fishers with modern fishing vessels and gear to enable them access offshore resources so as to prevent over-exploitation of the nearshore fisheries resources. This will also help to improve the living standard of the local fishermen through increased catches.

- Enforcement of the minimum offshore trawling distance of $3 \mathrm{~nm}$, regular use of onboard observers on trawlers to document target and bycatch species, mandatory use of Bycatch Reduction Devices, observation of the closed trawl season, and sustained prohibition of night trawling unless under research purposes.

\section{References}

Abuodha, J.O.Z. (2003). Grain size distribution and composition of modern dune and beach sediments, Malindi Bay coast Kenya. Journal of African Earth Sciences 36:4I-54.

Allison, E.H., Ellis, F. (2001). The livelihoods approach and management of small-scale fisheries. Marine Policy 25: $377-388$.

Alverson, D.L., Freeberg, M.H., Pope, J.G., Murawski, S.A. (1994). A global assessment of fisheries by-catch and discards. FAO Fisheries Technical Paper. No. 339. Rome, FAO. 233 pp.

Appeltans, W., Bouchet, P., Boxshall, G.A., de Broyer, C., de Voogd, N.J., Gordon, D.P., Hoeksema, B.W., Horton, T., Kennedy, M., Mees, J., Poore, G.C.B., Read, G., Stöhr, S., Walter, T.C., Costello, M.J. (eds). (2012). World Register of Marine Species. Accessed at http://www.marinespecies.org on 2012$05-18$.

Arntz, W.E., Tarazona, J. (1990). Effects of El Niňo $1982-83$ on benthos, fish and fisheries off the South American Pacific Coast. Oceanographic Series 52: 323-360.

Battaglia, P., Romeo, T., Consoli, P., Scotti, G., Andaloro, F. (2010). Characterisation of the artisanal fishery and its socio-economic aspects in the central Mediterranean Sea (Aelian Islands, Italy). Fisheries Research 102: 87-97. 
Bell, J.D., Kronen, M., Vunisea, A., Nash, W.J., Keeble, G., Demmke, A., Pontifex, S., Andrèfouët, S. (2009). Planning the use of fish for food security in the Pacific. Marine Policy 33 (I): $64-67$.

Benfield, M.C., Bosschieter, J.R., Forbes, A.T. (1989). Growth and emigration of Penaeus indicus H. MilneEdwards (Crustacea: Decapoda: Penaeidae) in the St. Lucia Estuary, Southern Africa. Fishery Bulletin 88, 2I-28.

Berks, F., Mahon, R., McConney, P., Pollnac, R., Pomeroy, R. (200I). Managing small-scale fisheries: alternative directions and methods. IDRC, Ottawa.

Bishop, J.M., Khan, M.H. (199I). Depth as a factor in abundance and size of juvenile penaeid shrimps in the absence of estuaries and marshes. Marine Biology I09: I03-II4.

Blaber, S.J.M., Brewer, D.T., Salini, J.P. (1989). Species composition and biomasses of fishes in different habitats of a tropical northern Australian fishery: their occurrence in the adjoining sea and estuarine dependence. Estuarine, Coastal and Shelf Science 29:509-531.

Blaber, S.J.M, Brewer, D.T., Salini, J.P., Kerr, J. (1990). Biomasses, catch rates and abundances of demersal fishes, particularly predators of prawns in a tropical bay in the Gulf of Carpentaria, Australia. Marine Biology I07(3): 397-408.

Bouillon, S., Dehairs, F. (2007). Biogeochemistry of the Tana estuary and delta (northern Kenya). Limnology Oceanography 52, 46-59.

Bouillon, S., Abril, G., Borges, A.V., Dehairs, F., Govers, G., Hughes, H., Merckx, R., Meysman, F.J.R., Nyunja, J., Osburn, C., Middelburg, J.J. (2009). Distribution, origin and cycling of carbon in the Tana River (Kenya): a dry season basin-scale survey from headwaters to the delta. Biogeosciences Discussion 6, 5959-6023.

British Admiralty Chart No. 3362. (1957). Malindi to Ras Chiambone. Region 5-R5. Scale: 300,000.

Bray, J.R, Curtis, J.T. (1957). An ordination of the upland forest communities of southern Wisconsin. Ecological Monographs 27: 325-349.

Caddy, J.F. (1999). Fisheries management in the twenty-first century: Will new paradigms apply? Reviews in Fish Biology and Fisheries 9: I-43.

Castello, L., Viana, J.P., Watkins, G., Pinedo-Vasquez, M., Luzadis, V.A. (2009). Lessons from integrating fishers of Arapaima in small-scale fisheries management at the Mamiraua Reserve, Amazon. Environmental Management 43: 197-209.

Chabanet, P., Durvel, P. (2005). Reef fish inventory of Juan de Nova's natural no-take area (Western Indian Ocean). Western Indian Ocean Journal of Marine Science 4: $145-162$.

Chong, K.C., Dwponngo, A., Ilyas, S., Martosubroto, P. (1987). Some experiences and highlights of the Indonesian trawl ban: bioeconomics and socio-economics. Indo-Pac Fish Comm RAPA rep ro: 458-477.

Chopin, F.S., Arimoto, T. (1995). The condition of fish escaping from fishing gear types: a review. Fisheries Research 21: 315-327.

Cinner, J.E., McClanahan, T.R., Graham, N.A.J., Pratchett, M.S., Wilson, S.K., Raina, J.B. (2009). Gearbased fisheries management as a potential adaptive response to climate change and coral mortality. Journal of Applied Ecology 46: 724-732.

Clarke, K.R., Warwick, R.M. (2001). Change in marine communities: an approach to statistical analysis and interpretation, 2nd edition. PRIMER-E: Plymouth.

Colloca, F., Crespi, V., Cerasi, S., Coppola, S.R. (2004). Structure and evolution of the artisanal fishery in Southern Italian coastal area. Fisheries Research 69: 359-369.

Dall, W., Hill, B.J., Rothisberg, P.C., Staples, D.J. (1990). The biology of the Penaeidae. Advanced Marine Biology $27, \mathrm{I}-489$.

Datoo, B.A. (1974). Influence of monsoons on movement of dhows along the East African coast. East Afric Geog Rev 12: 23-33.

Davies, T.E., Beanjara, N., Tregenza, T. (2009). Socio-economic perspective on gear-based management in an artisanal fishery in south-west Madagascar. Fisheries Management and Ecology i6: 279-289. 
de Freitas, A.J. (1986). Selection of nursery areas by six Southeast African Penaeidae. Estuarine Coastal and Shelf Science 23, 901-908.

- (2011). The Penaeoidea of South Africa IV - The Family Penaeidae: Genus Penaeus. Oceanographic Research Institute Investigational Report No. 59. 125pp.

Demetriades, N.T., Forbes, A.T. (1993). Seasonal changes in the species composition of the penaeid prawn catch on the Tugela Bank, Natal, South Africa. South African Journal of Marine Science 13, 317-322.

De Young, C., Charles, A., Hjort, A. (2008). Human dimensions of the ecosystem approach to fisheries: An overview of context, tools and methods. Fisheries technical paper No. 489. FAO, Rome Italy.

Douvere, F. (2008). The importance of marine spatial planning in advancing ecosystem-based sea use management. Marine Policy 32(5): 762-771.

Ellis, F. (1999). Rural livelihood diversity in developing countries: Evidence and policy implications. (Natural Resource Perspective 40). London: Overseas Development Institute.

- (2000). Rural livelihoods and diversity in developing countries. Oxford: Oxford University Press.

Eyo, E.A., Solarin, B.B., Isebor, C.E., Williams, A.B. (2005). Assessment of fish bycatch species from coastal artisanal shrimp beam trawl fisheries in Nigeria. Fisheries Research 71: 125-132.

FAO (2003). The ecosystem approach to fisheries. FAO technical guidelines for responsible fisheries, No. 4, suppliment 2. FAO Fisheries Department. Rome, II 2 pp.

- (2005). Putting into pactice the ecosystem approach to fisheris. Rome, FAO. 76 pp.

Farrugio, H., Oliver, P., Biagi, F. (1993). An overview of the history, knowledge, recent and future trends in Mediterranea fisheries. Scientia Marina 57: 105-119.

Fennessy, S.T. (1994). Incidental capture of elasmobranchs by commercial prawn trawlers on the Tugela Bank, Natal, South Africa. South African Journal of Marine Science I4: 287-296.

Fennessy, S.T., Mwatha, G.K., Thiele, W. (Eds). (2004). Report of the regional workshop on approaches to reducing shrimp trawl by-catch in the Western Indian Ocean. Mombasa, Kenya, 13-15 April 2003. FAO fisheries report. No.734. Rome, FAO.49pp.

Fennessy, S.T., Vincent, X., Budeba, Y., Mueni, E., Gove, D.Z. (2008). An update on initiatives to reduce prawn trawl by-catch in the Western Indian Ocean. Western Indian Ocean Journal of Marine Science 7(2): 217222.

Fischer, W., Bianchi, G. (1984). FAO species identification sheets for fishery purposes. Western Indian Ocean Fishing Area 5I. Vol. V.

Fisheries Department, Moi University. (2006). Status and impact of the prawn fishery in Malindi-Ungwana Bay: Implications for management and conservation. Ministry of Livestock and Fisheries Development. Unpublished technical report. $45 \mathrm{pp}$.

Friedlander, A.M., DeMartini, E.E. (2002). Contrasts in density, size and biomass of reef fishes between the northwestern and the main Hawaiian islands: the effects of fishing down apex predators. Marine Ecological Progress Series 230: 253-264.

Froese, R., Binohlan, C. (2000). Empirical relationships to estimate asymptotic length, length at first maturity and length at maximum yield per recruit in fishes with a simple method to evaluate length-frequency data. Journal of Fish Biology, 56: 758-773.

Froese, R., Pauly, D. (Eds). (2012). FishBase. World Wide Web electronic publication. www.fishbase.org, version (04/2012).

Forbes, A.T., Demetriades, N.T. (2005). A review of the commercial, shallow water penaeid prawn resource of South Africa: Status, fisheries, aquaculture and management. Specialist report prepared for Ezemvelo KZN Wildlife, South Africa. Marine and Estuarine Research. 64 pp.

Forbes, A.T., Benfield, M.C. (1986a.) Penaeid prawns in the St. Lucia Lake system: Post-larval recruitment and the bait fishery. South African Journal of Zoology 21, 224-228.

- (1986b). Tidal behaviour of post-larval penaeid prawns (Crustacea: Decapoda: Penaeidae) in a Southeast African estuary. Journal of Experimental Marine Biology 102, 23-34. 
Fulanda, B. (2003). Shrimp trawling in Ungwana Bay: A threat to fishery resources. In: Hoorweg J., Muthiga N. (eds.). Recent advances in coastal ecology: Studies from Kenya. PrintPartners Ipskamp Bv, Enschede, $233-42$.

Fulanda, B., Munga, C.N, Ohtomi, J., Osore, M., Mugo, R., Md. Hossain, Y. (2009). The structure and evolution of the coastal migrant fishery of Kenya. Ocean \& Coastal Management 52: 459-466.

Fulanda, B., Ohtomi, J., Mueni, E., Kimani, E. (20r I). Fishery trends, resource-use and management system in the Ungwana Bay fishery, Kenya. Ocean \& Coast Management 54: 40I-4I4.

Garcia, S.M., Cochrane, K.L. (2005). Ecosystem approach to fisheries: a review of implementation guideline1. ICES Journal of Marine Science 62: 311-318.

Garcia, S., le Reste, L. (198I). Life cycles, dynamics, exploitation and management of coastal penaeid shrimp stocks. FAO Fisheries Technical Paper, 203. Rome. 215 pp.

Garcia, A.M., Vieira, J.P., Winemiller, K.O. (2003). Effects of $1997-1998 \mathrm{El}$ Niňo on the dynamics of the shallow-water fish assemblage of the Patos Lagoon Estuary (Brazil). Estuarine Coastal and Shelf Science 57(3): $489-500$.

Gillet, R. (2008). Global study of shrimp fisheries. FAO document technique sur le peches. No. 475. Rome, FAO. $331 \mathrm{pp}$.

Glaesel, H. (1997). Fishers, parks, and power: The socio-environmental dimensions of marine resource decline and protection on the Kenya coast. (Ph.D. Thesis). Madison: University of Wisconsin.

Gobert, B. (1994). Size structures of demersal catches in multispecies multigear tropical fishery. Fisheries Research I9: 87-104.

Government of Kenya (1991). Fisheries Act Cap 378 - Laws of Kenya. Government Press, Nairobi.

- (2001). Gazette notice No. 7565 of 31/10/200I.

- (2002). Kenya 1999 population and housing census. Central Bureau of Statistics, Ministry of Finance and Planning. Nairobi, Kenya.

- (2008a). Kenya state of the coast report: towards the integrated management of Kenya's coastal and marine resources. UNEP and NEMA, Nairobi.gopp.

- (2008b). Marine waters fisheries frame survey 2008 report. Ministry of Fisheries Development, Department of Fisheries, Nairobi. 62 pp.

- (2009). Kenya Territorial Sea/Exclusive Economic Zone. Survey of Kenya.

- (2010a). Fisheries annual statistical bulletin 2010. Ministry of Fisheries Development, Department of Fisheries, Nairobi. 56 pp.

- (2010b). The prawn fishery management plan 2010. Kenya gazette supplement No.13. Legal notice No. 20. $8 \mathrm{pp}$.

- (2012). Marine waters fisheries frame survey 2012 report. Ministry of Fisheries Development, Department of Fisheries, Nairobi. 85 pp.

Gribblea, N.A., Wassenberg, T.J., Burridge, C. (2007). Factors affecting the distribution of commercially exploited penaeid prawns (shrimp) (Decapod: Penaeidae) across the northern Great Barrier Reef, Australia. Fisheries Research 85: 174-185.

Hall, M.A. (1996). On by-catches. Reviews in Fish Biology and Fisheries 6: 134-155.

Hall, M.A., Alverson, D.L., Metuzal, K.I. (200o). By-catch; problems and solutions; seas at millennium: an environmental evaluation. In: Sheppard CR (ed.). Global Issues and Processes 3: 135-15I.

Halliday, R.G., Pinhorn, A.T. (2002). A review of the scientific and technical bases for policies on the capture of small fish in North Atlantic groundfish fisheries. Fisheries Research 57: $211-222$.

Hardin, G. (1968). The tragedy of the commons. Science 162: 1243-1248.

Hicks, C.C., McClanahan, T.R. (2012). Assessing gear modifications needed to optimise yields in a heavily exploited, multispecies, sea grass and coral reef fishery. PloS ONE 7(5): e36022. Doi: I0.137I/journal. pone. 0036022 . 
Hill, B.J. (1975). Abundance, breeding and growth of the crab Scylla serrata in two South African estuaries. Marine Biology 32:119-126.

Holthuis, L.B. (1980). FAO species catalogue.Vol. 1.Shrimps and prawns of the world. FAO Fisheries Synopsis No. 125, I-27I.

Hoorweg, J., Versleijen, N., Wangila, B., Degen, A. (2006). Income diversification and fishing practices among artisanal fishers on the Malindi-Kilifi coast. In: Hoorweg, J., Muthiga, N. (eds.). Advances in coastal ecology: People, processes and ecosystems in Kenya. PrintPartners Ipskamp Bv, Enschede 20: 4I-59.

Hudson, A.V., Furness, R.W. (1988). Utilisation of discarded fish by scavenging seabirds behind white fish trawlers in Shetland. Journal of Zoology (London) 215: 151-166.

Hughes, D.A. (1966). Investigations of the "nursery areas" and habitat preferences of juvenile penaeid prawns in Mozambique. Journal of Applied Ecology 3, 349- 354.

Iversen, S.A. (1984). Kenyan marine fish resources in waters deeper than 10 meters investigated by R/V "DR. FRIDTJOF NANSEN". In: Iversen, S.A., Myklevoll, S. (eds.). Proceedings of the NORAD-Kenya seminar to review the marine fish stocks and fisheries in Kenya, 13-15 March 1984, Mombasa, Kenya.

Jennings, S., Kaiser, M.J. (1998). The effects of fishing on marine ecosystems. Advanced Marine Biology 34: 20I-35I.

Johannes, R.E. Freeman, M.R., Hamilton, R.J. 2000. Ignore fishers' knowledge and miss the boat. Fish and Fisheries I: 257-27I.

Jones, J.B. (1992). Environmental impact of trawling on the seabed: A review, New Zealand, Journal of Marine Freshwater Research 26: 59-67.

Kaiser, M.J., Collie, J.S., Hall, S.J., Jennings, S., Poiner, I.R. (2002). Modifications of marine habitats by trawling activities: prognosis and solution. Fish and Fisheries. 3: 114-136.

Kaiser, M.J., Spencer, B.E. (1996). The effects of beam trawl disturbance on faunal communities in different habitats. Journal of Animal Ecology 65: 48-358.

Kaiser, M.J., Hill, A.S., Ramsay, K., Spencer, B.E., Brand, A.R., Veal, L.O., Prudden, K., Rees, E.I.S., Munday, B.W., Ball, B., Hawkins, S.J. (1997). An estimate of fishing gear disturbance intensities in the Irish Sea: a comparison of beam trawling and scallop dredging. Aquatic Conservation 6: 269-285.

Kaunda-Arara, B., Rose, G.A., Muchiri, M.S. and Kaka, R. (2003). Long term trends in coral reef fish yields and exploitation rates of commercial species from coastal Kenya. Western Indian Ocean J. Mar. Sci. 2(2): I05-II6.

Kelleher, K. (2005). Discards in the world's marine fisheries. An update. FAO Fisheries Technical Paper. No. 470. Rome: FAO. 131 pp.

Kenya Bureau of Statistics. (2012). Kenya facts and figures. 83 pp.

Kenya Marine and Fisheries Research Institute (KMFRI) (2002). Current status of trawl fishery of MalindiUngwana Bay. Unpublished technical report. $97 \mathrm{pp}$.

Kimani, E., Manyala, J., Aura, C., Ndoro, C. (2010). Malindi-Ungwana Bay environment and prawn fisheries survey. Kenya Coastal Development Project, unpublished technical report. 66 pp.

Kimani, E., Manyala, J., Munga, C.N., Ndoro, C. (20II). Malindi-Ungwana Bay shallow water prawn survey SWIOFP Component 2. SWIOFP2orr 2ora. Unpublished technical report. 9I pp.

Kimani, E., Munga, C.N., Ndoro, C., Manyala, J., Thoya, P., Amisi, J. (2012). Malindi-Ungwana Bay shallow water prawn survey SWIOFP Component 2. SWIOFP2011C201b. Unpublished technical report. $49 \mathrm{pp}$.

Kimani, E., Munga, C.N., Thoya, P., Anam, R., Ruwa, R., Ong'anda, H., Ndoro, C. (2013). Deep water crustacean trawl survey SWIOFP Component 2. Voyage KEN20IIC203. SWIOFP survey technical report. $44 \mathrm{pp}$.

King, M.G. (1995). Fisheries biology, assessment and management. Fishing news books.Osney Mead, Oxford, England.34I pp.

Kitheka, J.U., Obiero, M., Nthenge, P. (2005). River discharge, sediment transport and exchange in the Tana estuary, Kenya. Estuarine and Coastal Shelf Science 63:455-468.

Kitheka, J.U. (2013). River sediment supply, sedimentation and transport of the highly turbid sediment plume in Malindi Bay, Kenya. Journal of Geographical Science 23(3): 465-489. 
Kolding, J., Zwieten P.A.M. (20II). The tragedy of our legacy: How do global management discourses affect small scale fisheries in the south?, Forum for Development Studies, 38(3): 267-297.

Kronen, M. (2004). Fishing for opportunities? A socio-economic assessment of Tonga's artisanal fisheries. Fisheries Research 70: 121-134.

Kronen, M., Vunisea, A., Magron, F., McArdle, B. (2010). Socio-economic drivers and indicators for artisanal coastal fisheries in Pacific island countries and territories and their use for fisheries management strategies. Marine Policy 34: II35-II43.

Kronen, M., Pinca, S., Magron, F., McArdle, B., Vunisea, A., Vigliola, L., Kulbicki, M.,Andrefouet, S. (2012). Socio-economic and fishery indicators to identify and monitor artisanal finfishing pressure in Pacific Island countries and territories. Ocean \& Coastal Management 55: 63-73.

Kulmiye, A.J., Mavuti, K.M. (2004). Growth and moulting of captive Panulirus homarus homarus in Kenya, Western Indian Ocean. Paper presented at the 7 th International Conference on lobster biology and man-

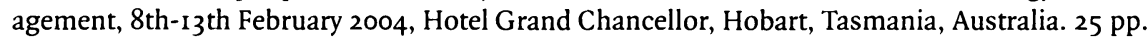

Kuster, C., Vuki, V., Zann, L. (2006). Validation of the accuracy of household reporting of subsistence fishing catch and effort: $a$ Fijian case study. Fisheries Management and Ecology 13: 177-184.

le Monach, F., Gough, C., Humber, F., Harper, S., Zeller, D. (2011). Reconstruction of total marine fisheries catches for Madagascar (1950 - 2008). Fisheries Centre Reports, Vol. I9 No. 4.I43 pp.

Lieske, E., Myers, R. (1994). Collins pocket guide to coral reef fishes: Indo-pacific and Caribbean. Herper Collins Publisher, London. $400 \mathrm{pp}$.

Loneragan, N.R., Bunn, S.E. (1999). River flows and estuarine ecosystems: Implications for coastal fisheries from a review and a case study of the Logan River, southeast Queensland. Australian Journal of Ecology 24:43I440.

Macia, A. (2004). Juvenile penaeid shrimp density, spatial distribution and size composition in four adjacent habitats within a mangrove-fringed bay on Inhaca Island, Mozambique. Western Indian Ocean Journal of Marine Science 3: $163-78$.

Mangi, S.C., Roberts, C.M., Rodwell, L.D. (2007). Reef fisheries management in Kenya: Preliminary approach using the driver-pressure-state-impacts-response (DPSIR) scheme of indicators. Ocean \& Coastal Management 50: $463-480$.

Mangi, S.C., Roberts, C.M. (2006). Quantifying the environmental impacts of artisanal fishing gear on Kenya's coral reef ecosystems. Marine Pollution Bulletin 52: 1646-1660.

Mathew, S. (2001). Small-scale fisheries perspectives on an ecosystem-based approach to fisheries management. Reykjavik Conference on Responsible Fisheries in the Marine Ecosystem. Reykjavik, Iceland: FAO, $18 \mathrm{pp}$.

McClanahan, T.R. (1988). Seasonality in East Africa's coastal waters. Marine Ecology Progress Series 44: 19I199.

McClanahan, T.R., Kaunda-Arara, B. (1996). Fish recovery in a coral reef marine no-take area and its effect on adjacent fishery. Conservation Biology 10: 1187-1199.

McClanahan, T.R., Young, T.P. (1996). East African ecosystems and their conservation. New York: Oxford University Press. Ioo pp.

McClanahan, T.R., Glaesel, H., Rubens, J., Kiambo, R. (1997). The effects of traditional fisheries management on fisheries yields and the coral-reef ecosystem of Southern Kenya. Environmental Conservation 24: 105I20.

McClanahan, T.R., Maina, J., Pet-Soede, L. (2002). Effects of the 1998 coral mortality event on Kenyan coral reefs and fisheries. Ambio 31: 7-8.

McClanahan, T.R., Mangi, S.C. (2004). Gear-based management of a tropical artisanal fishery based on species selectivity and capture size. Fisheries Management and Ecology II: $5 \mathrm{I}-60$.

McClanahan, T.R., Mwaguni, S., Muthiga, N.A. (2005). Management of the Kenyan coast. Ocean \& Coastal Management 48: 90I-93I. 
McClanahan, T.R., Cinner, J.E. (2J08). A framework for adaptive gear and ecosystem-based management in the artisanal coral reeffishery of Papua New Guinea. Aquatic Conservation: Marine and Freshwater Ecosystems I8: 493-507.

MacLennan, D.N. (1992). Fishing gear selectivity: an overview. Fisheries Research 13: $201-204$.

- (1995). Gear selectivity and variation of yield. ICES Journal of Marine Science 52: 827-836.

Martin, B. E. (1973). The History of Malindi. A Geographical Analysis of an East African Coastal Town from the Portuguese Period to Present. East African Literature Bureau. 30r pp.

Marquez-Farias, J.F. (2005). Gillnet mesh selectivity for the shovelnose guitarfish (Rhinobatus productus) from fishery-dependent data in the artisanal ray fishery of the Gulf of Carlifornia, Mexico. Journal of North West Atlantic Fisheries Science 35: 443-452.

Matic-Skoko, S., Staglicic, N., Pallaoro, A., Kraljevic, M., Dulcic, J., Tutman, P., Dragicevic, B. (2011). Effectiveness of conventional management in Mediterranean type artisanal fisheries. Estuarine, Coastal and Shelf Science 91: 314-324.

Mbuga, J. S. (1984). Fishing gears of the Kenya marine waters. In: S. A. Iversen and S. Myklevoll (Eds). The proceedings of the Norad-Kenya seminar to review the marine fish stocks and fisheries in Kenya Mombasa, Kenya, 13-15 March 1984.

Meltzer, L., Blinick, N.S., Fleishman, A.B. (2012). Management implications of the biodiversity and socioeconomic impacts of shrimp trawl by-catch in Bahia de Kino, Sonara, Mexico. PLoS ONE 7(6): e35609. doi:10.1371/journal.pone.0035609.

Middleton, J. (2000). The peoples. In: Hoorweg, J., Foeken, D., Obudho, R. (Eds.). Kenya Coast Handbook: Culture, resources and development in the East African littoral. roI-II4 pp.

Mkare, T.K. (2013). Genetic population structure of penaeid prawns Penaeus monodon Fabricius 1798 , Fenneropenaeus indicus H. Milne Edwards 1837 and Metapenaeus monoceros Fabricius 1798 in the Malindi-Ungwana Bay, Kenya. MSc Thesis. University of Stellenbosch, South Africa.

Mueni, E., Mwangi, J. (200I). A survey on the use of Turtle Excluder Devices (TEDs) in trawlers along the Kenyan coast. KWS Series-KESCOM Tech Rep I.

Munga, C.N., Mohamed, M.O.S., Obura, D.O., Vanreusel, A., Dahdouh-Guebas, F. (2010). Resource users' perceptions on continued existence of the Mombasa Marine Park and Reserve, Kenya. Western Indian Ocean Journal of Marine Science 9(2): 213-225.

Munga, C.N, Ndegwa S., Fulanda B., Manyala J., Kimani E., Ohtomi J. and Vanreusel A. (2012a). Bottom shrimp trawling impacts on species distribution and fishery dynamics; Ungwana Bay fishery Kenya before and after the 2006 trawl ban. Fisheries Science 78: 209-219.

Munga, C.N., Mohamed, M.O.S, Nassir, A., Dahdouh-Guebas, F., Obura, D.O., Vanreusel, A. (2012b). Status of coral reeffish communities within the Mombasa marine protected area, Kenya, more than a decade after establishment. Western Indian Ocean Journal of Marine Science IO(2): 169-184.

Munga, C.N., Mwangi, S., Ong'anda, H., Ruwa, R., Manyala, J., Groeneveld, J.C., Kimani, E. and Vanreusel, A. (2013). Species composition, distribution patterns and population structure of penaeid shrimps in Malindi-Ungwana Bay, Kenya, based on experimental bottom trawl surveys. Fisheries Research 147: 93-102.

Munro, J.L., Gaut, V.C., Thompson, R. (1973). Spawning seasons of Caribbean reeffishes. Journal of Fish Biology $5: 69-84$.

Mutagyera, W.B. (1984). Distribution of some deep water prawn and lobster species in Kenya's waters. In: Iversen, S.A. and Myklevoll, S. (eds). The proceedings of the NORAD-Kenya seminar to review the marine fish stocks and fisheries in Kenya, Mombasa, Kenya, 13-15 March 1984.

Mwatha, G.K. (2002). Assessment of the prawn fishery, by-catch, resource use conflicts and performance of the turtle excluder device. In: KMFRI. Current status of trawl fishery of Malindi-Ungwana Bay. Unpublished technical report. $97 \mathrm{pp}$.

(2005). Stock assessment and population dynamics of penaeid prawns in the prawn trawling grounds of $\mathrm{Ma}$ lindi-Ungwana Bay: The challenges of managing the prawn fishery in Kenya. WIOMSA/MARG-I/2005-06. 2I pp. 
Niamaimandi, N., Aziz, A., Khalijah, D.S., Roos, S., Kiabi, B. (2008). Reproductive biology of the green tiger prawn (Penaeus semisulcatus) in coastal waters of Bushehr, Persian Gulf. ICES Journal of Marine Science. Doi: $10.1093 /$ icesjms/fsn 172.

Nichols, S. (1990). The by-catch issue. In: The Mississippi shrimp industry. A management perspective. Proceedings of a Mississippi Sea Grant Advisory Service Workshop, Biloxi, Mississippi, April r989. Remy, K.H. (Ed.). Biloxi, Mississippi; Mississippi State University: 40-45.

Nzioka, R.M. (1979). Observations on the spawning seasons of East African reef fishes. Journal of Fish Biology 14: 329-342.

Ochiewo, J. (2004). Changing fisheries practices and their socio-economic implications in south coast Kenya. Ocean \& Coastal Management 47:389-408.

Ochiewo, I., Torre-Castro, M., Muthama, C., Munyi, F., Nthuta, J.M. (20ro). Socio-economic features of sea cucumber fisheries in southern coast of Kenya. Ocean \& Coastal Management 53: 192-202.

Olbers, J.M., Fennessy, S.T. (2007). A restrospective assessment of the stock status of Otolithes ruber (Pisces: Sciaenidae) as by-catch on prawn trawlers from KwaZulu-Natal, South Africa. African Journal of Marine Science 29(2): $247-252$.

Pallant, J. (2001). SPSS survival manual: A step by step guide to data analysis using SPSS for windows (versions 10 and 11). ISBN: $0335223664.352 \mathrm{pp}$.

Parsons, T.R.; Maita, Y., Lalli, C.M. (1984). A manual of chemical and biological methods for seawater analysis. Pergamon press. $173 \mathrm{pp}$.

Pauly, D. (1980). On the interrelationships between natural mortality, growth parameters and mean environmental temperature in 175 fish stocks. Journal du Conseil international pour l'Exploration de la Mer 39, 175I92.

Pauly, D., Murphy, G.I. (1982). Theory and management of tropical fisheries. ICLARM Conference Proceedinngs International Centre for Living Aquatic Resource Management (ICLARM) and Centre for Scientific and Industrial Research Organization (CSIRO). Ronulla, Australia. $360 \mathrm{pp}$.

Pauly, D., Palomares, M.L., Froese, R., Vakily, P.S.M., Preikshot, D., Wallace, S. (200I). Fishing down Canadian aquatic food webs. Canadian Journal of Fish and Aquatic Sciences 58: 51-62.

Pomeroy, R.S., Rivera-Guieb, R. (2006). Fishery Co-management: A practical handbook. Oxford University Press, Oxford. $288 \mathrm{pp}$.

Pontecorvo, G., Schrank, W.F. (2001). A small core fishery: a new approach to fisheries management. Marine Policy 25: 43-48.

Rabago-Quiroz, C.H., Lopez-Martinez, J., Herrera-Valdivia, E., Navare-Martinez, M.O.,RodriguezRomero, J. (2008). Population dynamics and spatial distribution of flatfish species in shrimp trawl bycatch in the Gulf of California. Hidrobiologica I8 (3): 177-188.

Roberts, C.M., Polunin, N.V.C. (1993). Marine reserves: Simple solutions to managing complex fisheries? Ambio 22: 363-368.

Teh, L.C.L., Teh, L.S.L., Starkhouse, B., Sumaila, U.R. (2009). An overview of socio-economic and ecological perspectives of Fiji's inshore reeffisheries. Marine Policy 33: 807-817.

Teikwa, E.D., Mgaya, Y.D. (2003). Abundance and reproductive biology of the Penaeid prawns of Bagamoyo coastal waters, Tanzania. Western Indian Ocean Journal of Marine Science 2, 117-126.

Tonks, M.L., Griffiths, S.P., Heales, D.S., Brewer, D.T., Dell, Q. (2008). Species composition and temporal variation of prawn trawl bycatch in the Joseph Bonaparte Gulf, northwesten Australia. Fisheries Research 89, 276-293.

Tremain, D.M., Adams, D.H. (1995). Seasonal variations in species diversity, abundance and composition of fish communities in the northern Indian River Lagoon, Florida. Bulletin of Marine Sciences 57: 171-192.

Turner, R., Cakacaka, A., Graham, N., Polunin, N., Pratchett, M., Stead, S. (2007). Declining resilience on marine resources in remote south Pacific societies: ecological versus socio-economic drivers. Coral Reefs 26: 9971008. 
Tychsen, J. (ed.). (2006). KenSea. Environmental sensitivity atlas for coastal areas of Kenya, 76 pp. Copenhagen; Geological Survey of Denmark and Greenland (GEUS); ISBN 87-7871-19I-6.

Saetersdal, G., Bianchi, G., Stromme, T., Venema, C. (1993). The Dr. Fridtjof Nansen Programme 1975-1993. Investigations of fishery resources in developing countries. History of the programme and review of results. FAO Fisheries Technical Paper No. 39r. Rome, FAO. 434 pp.

Salas, S., Chuenpagdee, R., Seijo, J.C., Charles, A. (2007). Challenges in the assessment and management of small-scale fisheries in Latin America and the Caribbean. Fisheries Research 87: 5-16.

Semesi, A.K., Mgaya, Y.D., Muruke, M.H.S, Francis, J., Mtolera, M., Msumi, G. (1998). Coastal resources utilisation and conservation issues in Bagamoyo. Ambio 27, 635-644.

Smith, T.D. (1994). Scaling fisheries. The science of measuring the effects of fishing, Cambridge: Cambridge University Press. Pp 1855-1955.

Smith, J.L.B., Heemstra, R. (1998). Smith's sea fishes. fourth ed. Valiant publishing santom, South Africa. $578 \mathrm{pp}$.

Somers, I.F. (1987). Sediment type as a factor in the distribution of prawn species in the Western Gulf of Carpentaria. Australian Journal of Marine Freshwater Research 38: 133-49.

- (1994). Species composition and distribution of commercial penaeid prawn catches in the Gulf of Carpentaria, Australia, in relation to depth and sediment type. Australian Journal of Marine Freshwater Research 45: 317-335.

Soykan, C.U., Moore, J.E., Zydelis, R., Crowder, L.B., Safina, C., Lewison, R.L. (2008). Why study by-catch? An introduction to the theme section on fisheries by-catch. Endangered Species Research 5: 9I-102.

Sparre, P., Ursin, E., Venema, S.C. (I989). Introduction to tropical fish stock assessment: Part 1 manual. FAO fisheries technical paper 306/I.

Staglicic, N., Matic-Skoko, A., Pallaoro, R., Grgicevic, M., Kraljevic, P., Tutman, B., Dulcic, D.J. (20rI). Long-term trends in the structure of eastern Adriatic littoral fish assemblages: Consequences for fisheries management. Estuarine, Coastal and Shelf Science 94: 263-27I.

Stearns, P.N. (Ed.)., (2001). The encyclopedia of world history: Ancient, medieval, and modern. Houghton Mifflin company, New York.

Stergiou, K.I., Erzini, K. (2002). Comparative fixed gear studies in the Cyclades (Aegian Sea): Size selectivity of small-hook longlines and monofilament gill nets. Fisheries Research 58: 25-40.

Stobutzki, I., Miller, M., Brewer, D. (200I). Sustainability of fishery bycatch: a process for assessing highly diverse and numerous bycatch. Environmental Conservation 28, 167-181.

Schwing, F.B., Palacios, D.M., Bograd, S.J. (2003). El Niňo impacts of the California current ecosystem. NOAA Fisheries, SWFSC, CA.

Schwing, F.B., Murphree, T., de Witt, L., Green, P.M. (2002). The evolution of oceanic and atmospheric anomalies in the Northeast Pacific during the El Niňo and La Niňa events of 1995-2000. Progressive Oceanography 54: 459-49I.

Tonks, M.L., Griffiths, S.P., Heales, D.S., Brewer, D.T., Dell, Q. (2008). Species composition and temporal variation of prawn trawl by-catch in the Joseph Bonaparte Gulf, northwesten Australia. Fisheries Research 89, 276-293.

van der Elst, R.P., Everret, B.I., Jiddawi, N., Mwatha, G., Alfonso, P.S., Boulle, D. (2005). Fish, fishers and fisheries of the Western Indian Ocean; their diversity and status, a preliminary assessment. Philosophical Transactions of the Royal Society of London A $363: 263-284$.

van der Elst, R.P. (198I). A guide to the common sea fishes of Southern African. Struik fisher Publishers, Cape Town 8001 , South Africa. 398 pp.

van Oostenbrugge, J.A.E., Bakker, E.J., van Densen, W.L.T, Michiels, M.A.M, van Zwieten, P.A.M. (2002). Characterising catch variability in a multispecies fishery: implications for fishery management. Canadian Journal of Fisheries and Aquuatic Science 59: 1032-1043. 
Vance, D.J., Heales, D.S., Loneragan, N.R. (1994). Seasonal, diel and tidal variation in beam-trawl catches of juvenile grooved tiger prawns, Penaeus semisulcatus (Decapoda: Penaeidae), in the Embley River, north-eastern Gulf of Carpentaria, Australia. Australian Journal of Marine and Freshwater Research 45, 35-42.

Venema, S.C. (1984). Review of marine resource surveys in Kenyan waters. In: Iversen, S.A., Myklevoll, S. (eds.). Proceedings of the NORAD-Kenya seminar to review the marine fish stocks and fisheries in Kenya, 13-15 March 1984, Mombasa, Kenya.

Wassenberg, T.J., Hill, B.J. (1989). The effect of trawling and subsequent handling on the survival of the by-catch of prawn trawlers in Moreton Bay, Australia. Fisheries Research 7: 99-Iro.

WWF (2004). Eastern African Marine Ecoregion. Towards a western Indian Ocean dugong conservation strategy: The status of dugongs in the western Indian Ocean region and priority conservation actions. Dar es Salaam, Tanzania, WWF. 68 pp.

Zar, J.H. (1999). Biostatistical analysis. Fourth Edition. Prentice-Hall, New Jersey. 663 pp. (main text) + $212 \mathrm{pp}$ (appendices). 